\title{
is Research Square \\ Epidemic Risk Perceptions in Italy and Sweden Driven by Authority Responses to COVID-19
}

Elena Raffetti ( $\square$ elena.raffetti@geo.uu.se )

Uppsala University

Elena Mondino

Uppsala University

Giuliano Di Baldassarre

Uppsala University

Research Article

Keywords: spread of disease outbreaks, epidemic risk, COVID-19

Posted Date: May 17th, 2021

DOI: https://doi.org/10.21203/rs.3.rs-484840/v1

License: (c) (1) This work is licensed under a Creative Commons Attribution 4.0 International License.

Read Full License 


\section{Abstract}

Understanding public risk perception is an essential step to develop effective measures reducing the spread of disease outbreaks. Here we compare epidemic risk perceptions during two different periods of the COVID-19 pandemic in Italy and Sweden. To this end, we analyzed the results of two nationwide surveys carried out in both countries in two periods characterized by different infection rates: August $(\mathrm{N}=$ 4,154) and November $2020(N=4,168)$. Seven domains of epidemic risk perception were considered: likelihood along with (individual and population) impact, preparedness, and knowledge. The role of the context and period was explored in stratified and formal interaction analyses. In both countries, we found an intensification in epidemic risk perception from August to November 2020. Being male, older and having a higher relative income were associated with a lower perception of the likelihood of epidemics, while excess mortality was marginally related to higher odds. Compared to Sweden, Italy had a higher increase in perception of likelihood and impact, and a concurrent decrease in preparedness and knowledge. The different authority response to the COVID-19 pandemic is associated with a different change over time in risk perception. Regional differences in terms of excess mortality only marginally explained differences in risk perception.

\section{Introduction}

Untangling public risk perception is a pivotal point to support the development of policies promoting public health and reducing disaster risk. Individual experience, trust, knowledge, and coping appraisal, along with sociocultural indicators, influence how people think about risks ${ }^{1-4}$. A direct experience of a major crisis, such as the ongoing COVID-19 pandemic, strongly reshapes public risk perceptions. The availability heuristic can play a role in this process, as people tend to evaluate the importance, seriousness and probability of a threat based on how easily it comes to their mind ${ }^{5}$. Yet, while direct experience tends to increase risk perception, high levels of trust in authorities often result in a lower risk perception ${ }^{1,6}$. This is partially explained by the shift of responsibility from the individual to the trusted authority. Similarly, feeling knowledgeable about a risk may increase the individual's coping appraisal, thus lowering their risk perception.

Along with a prompt response from authorities, public risk perception plays a crucial role to reduce the spread of disease outbreaks. Evidence from previous epidemics such as the Severe acute respiratory syndrome (SARS, 2003) and Swine flu (2009) suggests that individuals comply with national recommendations proportional to their risk perception ${ }^{7-9}$. In particular, perceiving a high likelihood to be infected and a high risk of severe complications of the disease, along with trusting that government and authorities are recommending effective behavioral changes to control the spread, can shape how people adhere to national recommendations.

Italy and Sweden were severely impacted during the first wave of the COVID-19 pandemic (spring 2020) ${ }^{10}$. The overall excess mortality was just below $30 \%$ in Italy and $20-25 \%$ in Sweden ${ }^{10}$. These dramatic figures can be partly attributed to the high proportion of people over 65 years in both Italy (23.0\%) and Sweden 
$(20.2 \%)$, which is substantially larger than the world average $(9.1 \%)^{11}$, as well as initial outbreaks in densely populated areas, namely the Lombardy Region (418 inhabitants $\left./ \mathrm{km}^{2}\right)$ in Italy and the Stockholm Region (367 inhabitants/ $\mathrm{km}^{2}$ ) in Sweden. The temporal evolution of COVID-19 deaths as well as daily occupancy of intensive care unit rates (ICU) in Italy and Sweden are presented in Fig. $1^{12,13}$. Both countries experienced a first epidemic peak in Spring 2020, which occurred in Italy a couple of weeks before Sweden, and the second peak in late Autumn 2020.

Although both Italy and Sweden have been highly affected by the first wave, the authority response and the distribution of the cases over time were different ${ }^{10}$. The world's second COVID-19 outbreak after Wuhan occurred in the Lombardy region, in Italy. It strongly impacted the local health care system and resulted in a nationwide stay-at-home order for the general population from the 10th of March to the beginning of May ${ }^{14}$. This response prevented major COVID-19 outbreaks in Southern Italy, which was only marginally affected by the first wave, and led to a geographical pattern in the spread of infection. As a result, $71.0 \%$ of the estimated excess deaths during the first wave (i.e. between March and May 2020) occurred in three Northern regions, with a few provinces with excess mortality up to $800 \%{ }^{15}$. Sweden was hit about two weeks later than Italy by the first COVID-19 wave (Fig. 1). In the second half of March, the Public Health Agency of Sweden recommended working from home and distance teaching (online) for high school and university students, along with a stay-at-home recommendation for risk groups (e.g. people older than 70 years) and those with respiratory symptoms ${ }^{14}$.

In this paper, we aim to unravel the role of authority responses on public perceptions of risk during the COVID-19 pandemic. To this end, we use observational data accrued in two countries (Italy and Sweden), which were severely affected by the COVID-19 pandemic, but with distinct authorities' responses characterized by different levels of restrictions. First, we compare public perceptions of epidemic risks in Italy and Sweden during two different periods of the COVID-19 pandemic. Next, we consider multiple factors associated with the different domains of risk perception. Finally, we explore the role of national policies and excess mortality in influencing risk perception.

\section{Results}

\section{Risk perception over time in Italy and Sweden}

We compared the risk perception of epidemics for seven domains between Italy and Sweden in two different periods of the COVID-19 pandemic (Fig. 2). Overall, the perception of how the epidemic impacted individuals, how individuals and authorities were prepared, and individual knowledge about epidemics were higher in Italy than in Sweden. Conversely, people in Italy perceived a lower likelihood of epidemics' occurrence and rated authorities' knowledge on epidemics lower than people in Sweden. Generally, from August 2020 to November 2020, there was an overall increase in average risk perception, increasing the likelihood and impact of epidemics, along with decreasing perceptions of individual and authority preparedness and knowledge. 
A formal interaction analysis supported a greater change in the magnitude of the associations in Italy compared to Sweden. Overall, a higher increase in perceived likelihood and impact, and a concurrent decrease in perceived preparedness and knowledge were observed (Table 1).

Table 1

Country (Italy vs. Sweden) effect modification on the association between period and pandemic risk perception.

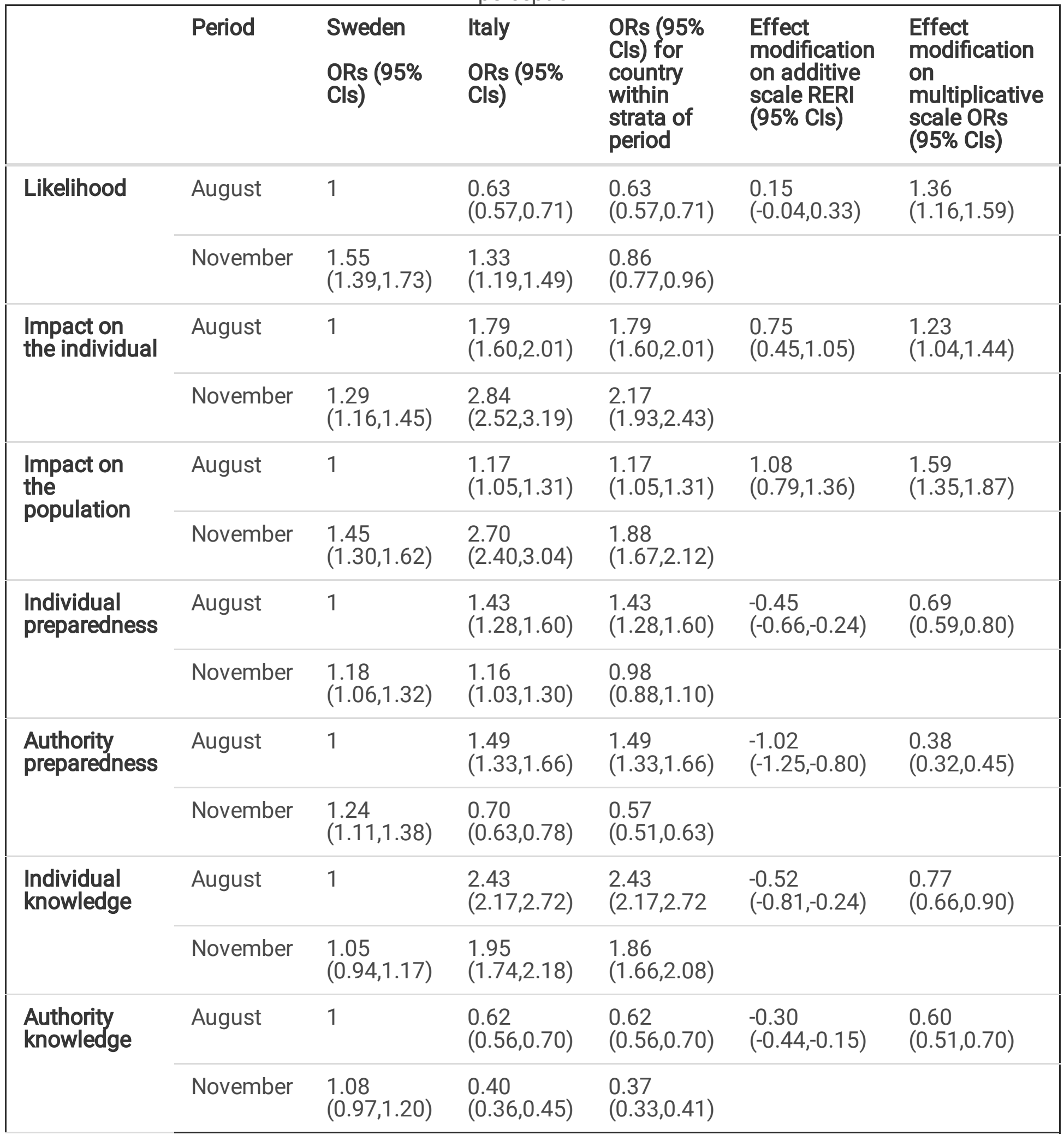


We found that the main factors related to risk perception were: i) direct experience with epidemics and ii) sociocultural factors such as gender, age, and relative income, with a substantial stable association across countries and over time (Table 2). 
Table 2

Factors associated with epidemic risk perception by country and period.

\begin{tabular}{|c|c|c|c|c|c|}
\hline & & Sweden & & Italy & \\
\hline & & August & November & August & November \\
\hline & & OR $(95 \% \mathrm{Cl})$ & OR (95\% Cl) & OR (95\% Cl) & OR $(95 \% \mathrm{Cl})$ \\
\hline \multirow[t]{7}{*}{ Likelihood } & Males & $\begin{array}{l}0.58 \\
(0.49,0.68)\end{array}$ & $\begin{array}{l}0.54 \\
(0.45,0.65)\end{array}$ & $\begin{array}{l}0.86 \\
(0.70,1.06)\end{array}$ & $\begin{array}{l}0.71 \\
(0.59,0.85)\end{array}$ \\
\hline & Age $50-69$ years & $\begin{array}{l}0.67 \\
(0.55,0.80)\end{array}$ & $\begin{array}{l}0.53 \\
(0.43,0.66)\end{array}$ & $\begin{array}{l}0.97 \\
(0.78,1.21)\end{array}$ & $\begin{array}{l}0.62 \\
(0.51,0.75)\end{array}$ \\
\hline & $\geq 70$ years & $\begin{array}{l}0.50 \\
(0.37,0.68)\end{array}$ & $\begin{array}{l}0.46 \\
(0.34,0.61)\end{array}$ & $\begin{array}{l}0.83 \\
(0.56,1.22)\end{array}$ & $\begin{array}{l}0.59 \\
(0.43,0.80)\end{array}$ \\
\hline & Employment & $\begin{array}{l}1.27 \\
(1.00,1.62)\end{array}$ & $\begin{array}{l}1.13 \\
(0.90,1.42)\end{array}$ & $\begin{array}{l}1.00 \\
(0.80,1.25)\end{array}$ & $\begin{array}{l}1.21 \\
(0.99,1.47)\end{array}$ \\
\hline & Relative income & $\begin{array}{l}0.96 \\
(0.89,1.04)\end{array}$ & $\begin{array}{l}0.91 \\
(0.84,1.00)\end{array}$ & $\begin{array}{l}0.89 \\
(0.81,0.98)\end{array}$ & $\begin{array}{l}0.99 \\
(0.91,1.07)\end{array}$ \\
\hline & $\begin{array}{l}\text { University } \\
\text { education }\end{array}$ & $\begin{array}{l}1.20 \\
(1.01,1.43)\end{array}$ & $\begin{array}{l}1.15 \\
(0.95,1.38)\end{array}$ & $\begin{array}{l}1.13 \\
(0.91,1.41)\end{array}$ & $\begin{array}{l}1.25 \\
(1.03,1.51)\end{array}$ \\
\hline & $\begin{array}{l}\text { Experience of } \\
\text { epidemics }\end{array}$ & $\begin{array}{l}3.16 \\
(2.59,3.85)\end{array}$ & $\begin{array}{l}3.51 \\
(2.81,4.37)\end{array}$ & $\begin{array}{l}3.16 \\
(2.52,3.96)\end{array}$ & $\begin{array}{l}2.49 \\
(2.08,2.99)\end{array}$ \\
\hline \multirow[t]{7}{*}{$\begin{array}{l}\text { Impact on the } \\
\text { individual }\end{array}$} & Males & $\begin{array}{l}0.80 \\
(0.68,0.95)\end{array}$ & $\begin{array}{l}0.58 \\
(0.48,0.69)\end{array}$ & $\begin{array}{l}0.69 \\
(0.56,0.85)\end{array}$ & $\begin{array}{l}0.71 \\
(0.59,0.85)\end{array}$ \\
\hline & Age $50-69$ years & $\begin{array}{l}1.50 \\
(1.24,1.81)\end{array}$ & $\begin{array}{l}1.80 \\
(1.45,2.23)\end{array}$ & $\begin{array}{l}1.25 \\
(1.01,1.56)\end{array}$ & $\begin{array}{l}1.32 \\
(1.09,1.61)\end{array}$ \\
\hline & $\geq 70$ years & $\begin{array}{l}1.49 \\
(1.08,2.07)\end{array}$ & $\begin{array}{l}3.50 \\
(2.59,4.72)\end{array}$ & $\begin{array}{l}0.93 \\
(0.64,1.36)\end{array}$ & $\begin{array}{l}1.72 \\
(1.27,2.32)\end{array}$ \\
\hline & Employment & $\begin{array}{l}0.76 \\
(0.59,0.97)\end{array}$ & $\begin{array}{l}1.04 \\
(0.83,1.32)\end{array}$ & $\begin{array}{l}0.90 \\
(0.72,1.13)\end{array}$ & $\begin{array}{l}1.03 \\
(0.85,1.25)\end{array}$ \\
\hline & Relative income & $\begin{array}{l}0.87 \\
(0.80,0.94)\end{array}$ & $\begin{array}{l}0.89 \\
(0.82,0.98)\end{array}$ & $\begin{array}{l}0.83 \\
(0.75,0.91)\end{array}$ & $\begin{array}{l}0.96 \\
(0.89,1.04)\end{array}$ \\
\hline & $\begin{array}{l}\text { University } \\
\text { education }\end{array}$ & $\begin{array}{l}1.07 \\
(0.90,1.28)\end{array}$ & $\begin{array}{l}1.31 \\
(1.08,1.58)\end{array}$ & $\begin{array}{l}1.21 \\
(0.97,1.51)\end{array}$ & $\begin{array}{l}1.03 \\
(0.85,1.24)\end{array}$ \\
\hline & $\begin{array}{l}\text { Experience of } \\
\text { epidemics }\end{array}$ & $\begin{array}{l}1.45 \\
(1.18,1.78)\end{array}$ & $\begin{array}{l}1.27 \\
(1.02,1.58)\end{array}$ & $\begin{array}{l}1.22 \\
(0.99,1.52)\end{array}$ & $\begin{array}{l}1.52 \\
(1.27,1.82)\end{array}$ \\
\hline \multirow[t]{2}{*}{$\begin{array}{l}\text { Impact on the } \\
\text { population }\end{array}$} & Males & $\begin{array}{l}0.57 \\
(0.49,0.68)\end{array}$ & $\begin{array}{l}0.50 \\
(0.42,0.60)\end{array}$ & $\begin{array}{l}0.61 \\
(0.50,0.76)\end{array}$ & $\begin{array}{l}0.48 \\
(0.40,0.59)\end{array}$ \\
\hline & Age $50-69$ years & $\begin{array}{l}0.89 \\
(0.74,1.08)\end{array}$ & $\begin{array}{l}1.06 \\
(0.86,1.31)\end{array}$ & $\begin{array}{l}1.17 \\
(0.93,1.46)\end{array}$ & $\begin{array}{l}1.48 \\
(1.19,1.82)\end{array}$ \\
\hline
\end{tabular}




\begin{tabular}{|c|c|c|c|c|c|}
\hline & & Sweden & & Italy & \\
\hline & $\geq 70$ years & $\begin{array}{l}0.67 \\
(0.49,0.91)\end{array}$ & $\begin{array}{l}1.18 \\
(0.88,1.58)\end{array}$ & $\begin{array}{l}0.77 \\
(0.53,1.13)\end{array}$ & $\begin{array}{l}1.75 \\
(1.27,2.41)\end{array}$ \\
\hline & Employment & $\begin{array}{l}1.02 \\
(0.80,1.30)\end{array}$ & $\begin{array}{l}1.33 \\
(1.06,1.68)\end{array}$ & $\begin{array}{l}0.80 \\
(0.64,1.02)\end{array}$ & $\begin{array}{l}0.92 \\
(0.75,1.14)\end{array}$ \\
\hline & Relative income & $\begin{array}{l}0.84 \\
(0.77,0.90)\end{array}$ & $\begin{array}{l}0.87 \\
(0.80,0.95)\end{array}$ & $\begin{array}{l}0.86 \\
(0.78,0.94)\end{array}$ & $\begin{array}{l}0.97 \\
(0.89,1.06)\end{array}$ \\
\hline & $\begin{array}{l}\text { University } \\
\text { education }\end{array}$ & $\begin{array}{l}1.06 \\
(0.89,1.26)\end{array}$ & $\begin{array}{l}1.05 \\
(0.87,1.27)\end{array}$ & $\begin{array}{l}1.22 \\
(0.97,1.54)\end{array}$ & $\begin{array}{l}1.05 \\
(0.85,1.29)\end{array}$ \\
\hline & $\begin{array}{l}\text { Experience of } \\
\text { epidemics }\end{array}$ & $\begin{array}{l}1.87 \\
(1.53,2.27)\end{array}$ & $\begin{array}{l}1.87 \\
(1.51,2.33)\end{array}$ & $\begin{array}{l}1.73 \\
(1.37,2.17)\end{array}$ & $\begin{array}{l}1.56 \\
(1.28,1.90)\end{array}$ \\
\hline $\begin{array}{l}\text { Individual } \\
\text { preparedness }\end{array}$ & Males & $\begin{array}{l}0.78 \\
(0.66,0.92)\end{array}$ & $\begin{array}{l}0.74 \\
(0.62,0.89)\end{array}$ & $\begin{array}{l}1.47 \\
(1.19,1.80)\end{array}$ & $\begin{array}{l}1.54 \\
(1.29,1.84)\end{array}$ \\
\hline & Age $50-69$ years & $\begin{array}{l}1.45 \\
(1.21,1.74)\end{array}$ & $\begin{array}{l}1.40 \\
(1.14,1.71)\end{array}$ & $\begin{array}{l}1.16 \\
(0.94,1.44)\end{array}$ & $\begin{array}{l}0.83 \\
(0.69,1.01)\end{array}$ \\
\hline & $\geq 70$ years & $\begin{array}{l}1.49 \\
(1.09,2.02)\end{array}$ & $\begin{array}{l}1.26 \\
(0.95,1.68)\end{array}$ & $\begin{array}{l}1.44 \\
(1.00,2.06)\end{array}$ & $\begin{array}{l}0.83 \\
(0.61,1.12)\end{array}$ \\
\hline & Employment & $\begin{array}{l}1.07 \\
(0.84,1.35)\end{array}$ & $\begin{array}{l}0.86 \\
(0.69,1.07)\end{array}$ & $\begin{array}{l}1.05 \\
(0.84,1.32)\end{array}$ & $\begin{array}{l}0.99 \\
(0.82,1.20)\end{array}$ \\
\hline & Relative income & $\begin{array}{l}1.11 \\
(1.03,1.20)\end{array}$ & $\begin{array}{l}1.09 \\
(1.00,1.19)\end{array}$ & $\begin{array}{l}1.24 \\
(1.13,1.37)\end{array}$ & $\begin{array}{l}1.21 \\
(1.12,1.31)\end{array}$ \\
\hline & $\begin{array}{l}\text { University } \\
\text { education }\end{array}$ & $\begin{array}{l}1.08 \\
(0.91,1.29)\end{array}$ & $\begin{array}{l}1.13 \\
(0.94,1.36)\end{array}$ & $\begin{array}{l}1.31 \\
(1.05,1.63)\end{array}$ & $\begin{array}{l}1.02 \\
(0.85,1.24)\end{array}$ \\
\hline & $\begin{array}{l}\text { Experience of } \\
\text { epidemics }\end{array}$ & $\begin{array}{l}2.22 \\
(1.82,2.70)\end{array}$ & $\begin{array}{l}1.92 \\
(1.55,2.38)\end{array}$ & $\begin{array}{l}1.21 \\
(0.98,1.50)\end{array}$ & $\begin{array}{l}1.66 \\
(1.39,1.98)\end{array}$ \\
\hline $\begin{array}{l}\text { Authority } \\
\text { preparedness }\end{array}$ & Males & $\begin{array}{l}0.57 \\
(0.48,0.67)\end{array}$ & $\begin{array}{l}0.67 \\
(0.56,0.79)\end{array}$ & $\begin{array}{l}1.00 \\
(0.82,1.23)\end{array}$ & $\begin{array}{l}1.23 \\
(1.03,1.46)\end{array}$ \\
\hline & Age $50-69$ years & $\begin{array}{l}1.16 \\
(0.97,1.39)\end{array}$ & $\begin{array}{l}1.35 \\
(1.11,1.65)\end{array}$ & $\begin{array}{l}1.21 \\
(0.98,1.50)\end{array}$ & $\begin{array}{l}0.97 \\
(0.81,1.17)\end{array}$ \\
\hline & $\geq 70$ years & $\begin{array}{l}1.22 \\
(0.90,1.64)\end{array}$ & $\begin{array}{l}1.07 \\
(0.81,1.42)\end{array}$ & $\begin{array}{l}1.38 \\
(0.96,1.97)\end{array}$ & $\begin{array}{l}1.18 \\
(0.89,1.57)\end{array}$ \\
\hline & Employment & $\begin{array}{l}1.20 \\
(0.96,1.51)\end{array}$ & $\begin{array}{l}0.82 \\
(0.65,1.02)\end{array}$ & $\begin{array}{l}0.82 \\
(0.66,1.03)\end{array}$ & $\begin{array}{l}1.05 \\
(0.88,1.27)\end{array}$ \\
\hline & Relative income & $\begin{array}{l}1.14 \\
(1.06,1.23)\end{array}$ & $\begin{array}{l}1.21 \\
(1.11,1.31)\end{array}$ & $\begin{array}{l}1.20 \\
(1.10,1.32)\end{array}$ & $\begin{array}{l}1.16 \\
(1.07,1.25)\end{array}$ \\
\hline & $\begin{array}{l}\text { University } \\
\text { education }\end{array}$ & $\begin{array}{l}1.09 \\
(0.92,1.29)\end{array}$ & $\begin{array}{l}1.12 \\
(0.93,1.34)\end{array}$ & $\begin{array}{l}1.02 \\
(0.83,1.26)\end{array}$ & $\begin{array}{l}0.98 \\
(0.81,1.18)\end{array}$ \\
\hline & $\begin{array}{l}\text { Experience of } \\
\text { epidemics }\end{array}$ & $\begin{array}{l}1.10 \\
(0.91,1.33)\end{array}$ & $\begin{array}{l}1.26 \\
(1.02,1.54)\end{array}$ & $\begin{array}{l}1.07 \\
(0.86,1.32)\end{array}$ & $\begin{array}{l}1.10 \\
(0.92,1.30)\end{array}$ \\
\hline
\end{tabular}




\begin{tabular}{|c|c|c|c|c|c|}
\hline & & Sweden & & Italy & \\
\hline \multirow[t]{7}{*}{$\begin{array}{l}\text { Individual } \\
\text { knowledge }\end{array}$} & Males & $\begin{array}{l}0.76 \\
(0.65,0.90)\end{array}$ & $\begin{array}{l}0.83 \\
(0.70,0.99)\end{array}$ & $\begin{array}{l}1.15 \\
(0.94,1.41)\end{array}$ & $\begin{array}{l}1.03 \\
(0.87,1.23)\end{array}$ \\
\hline & Age $50-69$ years & $\begin{array}{l}1.12 \\
(0.93,1.34)\end{array}$ & $\begin{array}{l}1.14 \\
(0.93,1.39)\end{array}$ & $\begin{array}{l}1.23 \\
(1.00,1.53)\end{array}$ & $\begin{array}{l}0.87 \\
(0.72,1.05)\end{array}$ \\
\hline & $\geq 70$ years & $\begin{array}{l}1.27 \\
(0.94,1.73)\end{array}$ & $\begin{array}{l}0.94 \\
(0.71,1.25)\end{array}$ & $\begin{array}{l}0.92 \\
(0.64,1.33)\end{array}$ & $\begin{array}{l}0.73 \\
(0.55,0.98)\end{array}$ \\
\hline & Employment & $\begin{array}{l}0.92 \\
(0.72,1.16)\end{array}$ & $\begin{array}{l}0.97 \\
(0.77,1.21)\end{array}$ & $\begin{array}{l}1.25 \\
(1.00,1.56)\end{array}$ & $\begin{array}{l}0.89 \\
(0.74,1.07)\end{array}$ \\
\hline & Relative income & $\begin{array}{l}1.05 \\
(0.98,1.14)\end{array}$ & $\begin{array}{l}1.09 \\
(1.01,1.19)\end{array}$ & $\begin{array}{l}1.19 \\
(1.08,1.31)\end{array}$ & $\begin{array}{l}1.23 \\
(1.14,1.33)\end{array}$ \\
\hline & $\begin{array}{l}\text { University } \\
\text { education }\end{array}$ & $\begin{array}{l}1.75 \\
(1.47,2.07)\end{array}$ & $\begin{array}{l}1.57 \\
(1.31,1.89)\end{array}$ & $\begin{array}{l}1.00 \\
(0.81,1.25)\end{array}$ & $\begin{array}{l}1.34 \\
(1.11,1.61)\end{array}$ \\
\hline & $\begin{array}{l}\text { Experience of } \\
\text { epidemics }\end{array}$ & $\begin{array}{l}2.53 \\
(2.07,3.07)\end{array}$ & $\begin{array}{l}2.74 \\
(2.21,3.40)\end{array}$ & $\begin{array}{l}1.16 \\
(0.94,1.44)\end{array}$ & $\begin{array}{l}1.33 \\
(1.12,1.58)\end{array}$ \\
\hline \multirow[t]{7}{*}{$\begin{array}{l}\text { Authority } \\
\text { knowledge }\end{array}$} & Males & $\begin{array}{l}0.79 \\
(0.67,0.92)\end{array}$ & $\begin{array}{l}0.88 \\
(0.74,1.05)\end{array}$ & $\begin{array}{l}1.13 \\
(0.92,1.38)\end{array}$ & $\begin{array}{l}1.29 \\
(1.08,1.53)\end{array}$ \\
\hline & Age $50-69$ years & $\begin{array}{l}1.01 \\
(0.84,1.20)\end{array}$ & $\begin{array}{l}1.14 \\
(0.93,1.39)\end{array}$ & $\begin{array}{l}1.43 \\
(1.16,1.77)\end{array}$ & $\begin{array}{l}0.92 \\
(0.76,1.11)\end{array}$ \\
\hline & $\geq 70$ years & $\begin{array}{l}1.06 \\
(0.78,1.43)\end{array}$ & $\begin{array}{l}0.66 \\
(0.50,0.87)\end{array}$ & $\begin{array}{l}1.64 \\
(1.13,2.38)\end{array}$ & $\begin{array}{l}0.89 \\
(0.67,1.19)\end{array}$ \\
\hline & Employment & $\begin{array}{l}1.04 \\
(0.82,1.32)\end{array}$ & $\begin{array}{l}0.79 \\
(0.63,0.99)\end{array}$ & $\begin{array}{l}0.97 \\
(0.78,1.21)\end{array}$ & $\begin{array}{l}0.93 \\
(0.77,1.12)\end{array}$ \\
\hline & Relative income & $\begin{array}{l}1.27 \\
(1.18,1.38)\end{array}$ & $\begin{array}{l}1.26 \\
(1.16,1.37)\end{array}$ & $\begin{array}{l}1.32 \\
(1.20,1.45)\end{array}$ & $\begin{array}{l}1.25 \\
(1.16,1.35)\end{array}$ \\
\hline & $\begin{array}{l}\text { University } \\
\text { education }\end{array}$ & $\begin{array}{l}1.47 \\
(1.24,1.74)\end{array}$ & $\begin{array}{l}1.20 \\
(1.00,1.44)\end{array}$ & $\begin{array}{l}0.96 \\
(0.77,1.19)\end{array}$ & $\begin{array}{l}0.98 \\
(0.81,1.18)\end{array}$ \\
\hline & $\begin{array}{l}\text { Experience of } \\
\text { epidemics }\end{array}$ & $\begin{array}{l}1.50 \\
(1.24,1.81)\end{array}$ & $\begin{array}{l}1.47 \\
(1.19,1.80)\end{array}$ & $\begin{array}{l}1.07 \\
(0.86,1.33)\end{array}$ & $\begin{array}{l}1.25 \\
(1.05,1.49)\end{array}$ \\
\hline
\end{tabular}

Direct experience of epidemics was the main driver of perceived likelihood of epidemics with a 2.49 to 3.16-fold higher odds. On the other hand, being male, older age, along with having a higher relative income were associated with a lower perceived likelihood of epidemics.

Focusing on the perceived impact of the epidemic at the individual and population level, direct experience of epidemics was related with a 1.22 to 1.52 higher odds, while being male and having a high relative income with a lower odds. Compared to younger generations, the elderly in Sweden perceived an important impact on the individual up to 3.5-fold increased odds in November. Concern among the elderly in Italy also increased between August and November for both individual (from 0.93 to $1.72 \mathrm{OR}$ ) and population impact (from 0.77 to $1.75 \mathrm{OR}$ ). 
For perceived preparedness, having a higher relative income was positively associated with both individual and authorities' preparedness, while the experience of epidemics was mainly related to a higher perceived individual preparedness ( 1.21 to $2.22 \mathrm{OR}$ ). Males compared to females perceived lower individual and authorities' preparedness in Sweden, a relationship in the opposite direction was observed in Italy (see Table 2).

Finally, the experience of epidemics and university education were associated with perceiving a higher level of individual and authorities' knowledge.

\section{How the excess mortality and national policies influence the risk perception}

The first COVID-19 wave impacted Italy and Sweden to a different extent. Figure 3 compared the assessed risk perception in the most affected region, Stockholm region in Sweden and Lombardy region in Italy, with the rest of the country. Yet, the average risk perception did not reflect these geographical patterns and it was similar within countries. The only exception was a higher likelihood of epidemics in August, just after the first wave, in the most affected regions for both countries. Just at the beginning of the second wave (November), individuals living in the most affected regions perceived a lower individual knowledge in Italy and higher individual preparedness in Sweden compared to the rest of the population.

Figure 4 shows the excess mortality and likelihood of epidemics at regional level in Italy and Sweden. Despite significant differences in excess mortality among Italian and Swedish regions, the perception of likelihood of epidemics was quite similar within countries. Looking at the role of excess mortality as a predictor of risk perception domains, the excess mortality seemed only to marginally explain the likelihood of epidemics while no association was found with other domains (Table 3).

Table 3

Association between excess mortality (for each 10\% increase) and domains of risk perceptions.

\begin{tabular}{|lll|}
\hline & $\begin{array}{l}\text { Sweden } \\
\text { ORs }(95 \% \mathrm{Cls})\end{array}$ & $\begin{array}{l}\text { Italy } \\
\text { ORs (95\% Cls) }\end{array}$ \\
\hline Likelihood & $1.07(1.03,1.11)$ & $1.03(1.01,1.06)$ \\
\hline Impact on the individual & $1.02(0.98,1.06)$ & $0.99(0.97,1.01)$ \\
\hline Impact on the population & $1.01(0.97,1.04)$ & $0.98(0.96,1.00)$ \\
\hline Individual preparedness & $0.97(0.93,1.00)$ & $1.00(0.98,1.02)$ \\
\hline Authority preparedness & $0.94(0.91,0.97)$ & $0.97(0.95,0.99)$ \\
\hline Individual knowledge & $1.01(0.98,1.05)$ & $0.98(0.96,1.00)$ \\
\hline Authority knowledge & $0.95(0.92,0.98)$ & $0.97(0.95,0.99)$ \\
\hline Models adjusted for gender, age and relative income. \\
\hline
\end{tabular}


Moving to the role of national policy responses, Fig. 1 describes the change over time of the level of measures (Stringency Index, ranging from 0 to 100, $100=$ strictest) implemented in Italy and Sweden ${ }^{16}$. The level of restrictions was higher in Italy (maximum 93.4) than in Sweden (maximum 64.8) during the first wave. This index was positively associated with perceived likelihood, impact along with individual knowledge and preparedness and negatively associated with authority knowledge and preparedness (Table 4).

Table 4

Association between the level of national policy response (Stringency index) and domains of risk perceptions.

\begin{tabular}{|ll|}
\hline & ORs (95\% Cls) \\
\hline Likelihood & $1.74(1.52,2.00)$ \\
\hline Impact on the individual & $3.06(2.65,3.53)$ \\
\hline Impact on the population & $3.28(2.84,3.78)$ \\
\hline Individual preparedness & $1.22(1.06,1.40)$ \\
\hline Authority preparedness & $0.72(0.63,0.82)$ \\
\hline Individual knowledge & $1.80(1.57,2.06)$ \\
\hline Authority knowledge & $0.45(0.39,0.51)$ \\
\hline Models adjusted for gender, age and relative income. \\
\hline
\end{tabular}

\section{Discussion}

In both countries, there was an overall intensification in average risk perception from August to November 2020 , characterized by an increase in perceived likelihood and impact of epidemics, along with a decrease in perceived individual and authorities' preparedness and knowledge. This may be of concern as, according to the Protection Motivation Theory ${ }^{17,18}$, a high threat appraisal paired with a low coping appraisal may result in the choice of not protecting oneself. In the case of COVID-19, this poses a risk not only to the individual, but also to others around them. Being male, older age along with having a higher relative income were associated with a lower perception of the likelihood of epidemics, while excess mortality was marginally related to a higher odds. People in Italy had a higher increase in perception of likelihood and impact of epidemics compared to Sweden and a greater decrease in perceived preparedness and knowledge were observed over time. Regional differences in excess mortality within each country only marginally explained differences in the risk perception.

How a pandemic affects a population stems from the interplay of different factors: population characteristics, prompt response to the spreading, and preparedness of the health care system ${ }^{10}$. While preparedness of the health care system requires years to establish and is continuously evolving, a 
prepared contingency plan can be implemented within days. From past pandemics, we know that the success of policies and responses to reduce the infection rate and to avoid epidemics depends on risk perception and behavioral adaptation to such policies and response measures ${ }^{19}$. Increasing COVID-19 cases, media coverage and implementation of more restrictive measures may have contributed to the increase in the average risk perception from August 2020 to the beginning of the second wave of the COVID-19 pandemic (November 2020) in our sample. Cross-sectional surveys on risk perception of the COVID-19 pandemic found a positive association between higher risk perception and higher compliance to preventive measures ${ }^{20,21}$. Thus, the increased risk perception in the present study may result in people applying behavioral measures such as social distancing, hand washing, avoidance of public places and transports, and wearing face masks.

As reported in previous studies, our findings support the theory of lower risk perception among individuals with a traditionally higher status in society ${ }^{22}$. Men, the elderly population and individuals with a higher income perceived a lower risk compared to women, younger generations and individuals with lower income, respectively as shown in other surveys ${ }^{23,24}$. Media coverage and public messages from the authorities can increase awareness of the impact of COVID-19 infection, in turn facilitating engagement in protective behaviors, especially among men and the elderly - two groups at risk for severe consequences if infected ${ }^{25}$. Along with this, governments should consider the negative consequences that disadvantaged socio-economic groups are facing and should address rising inequalities following the pandemic.

How excess mortality and national policies during the first wave affect the epidemic risk perception is another important aspect to disentangle. In the present study, excess mortality at regional level was marginally associated with perceived likelihood of epidemics. Comparing Italian and Swedish authorities' responses during the COVID-19 pandemic may help to untangle the role of national policies. The more stringent measures in Italy during the first wave may explain the higher risk perception in August, and the application of stronger measures at the beginning of the second wave (November 2020) may justify a higher increase of risk perception in Italy than in Sweden over three months. Generally, national policies rather than excess mortality may influence the risk perception since national recommendations and restrictions affect all the population, while few households are affected by the epidemic, even in a scenario with $100 \%$ excess mortality.

Findings from this study shed light on the change of public risk perception during the current pandemic informing the scientific community and policymakers. At odds with other threats, individuals have a double role during a pandemic: protecting themselves and safeguarding vulnerable groups at the greatest risk. Implementing personal hygiene measures and adhering to national policies are both required to slow the speed of infection and reduce the burden on the health care system. In our study, high levels of risk perception resulted in a lower trust in authorities with a possible shift of responsibility from trusted authority to individuals. This reduction in perceived authority knowledge and preparedness was stronger in Italy, a country where the restrictions were imposed, compared to Sweden, where the policies have been mainly based on recommendations. A reduction over time of trust in the authorities is of concern since it may affect the adherence to imposed measures. Modern democracies rely on a social contract where each 
individual should contribute to the collective well-being in proportion to their abilities and exercise their right to vote through their representatives ${ }^{26}$. Imposing measures to limit personal freedom has a positive effect in the short term to reduce the spread of infection. From a long-term perspective, a paternalistic approach may lead to the emergence of conflicts, non-adherence of imposed measures, and the disruption of the social contract. Policymakers should encourage community involvement and make communities the centre of the response to this pandemic. This approach can help to obtain adherence to the necessary preventive measures and defend the social contract on which modern democracies are based.

A number of additional limitations should be kept in mind when interpreting findings from our study. First, domains of risk perceptions should be interpreted in terms of change over time rather than absolute values given that cultural belief and other country-level factors may affect absolute values. Second, we considered independent samples of the population in the first and second survey wave. Although the samples should be considered representative of the general populations for age and gender, other individual differences may influence the changes over time. Third, this study does not allow to disentangle the specific role of restrictive measures and media coverage as determinants of risk perception.

Conclusively, our findings indicate an increased average epidemic risk perception during the COVID-19 pandemic from August to November 2020. Being male, elderly and a high income was related with a lower risk perception. Considering country-level factors, national policy response rather than excess mortality was an important determinant of the risk perception. In the future months, efforts should be directed towards monitoring the change of risk perception over time, investigating if a higher risk perception is associated with adherence to national recommendations also for the COVID-19 pandemic and untangling the role of media coverage and recommendations on risk perception.

\section{Methods}

\section{Study population}

We included data from an anonymous survey on public risk perception carried out in Italy and Sweden in two different periods of the COVID-19 pandemic. Detailed information on the study has been published elsewhere ${ }^{27}$. In brief, the survey explores the public risk perception for nine threats (epidemics, floods, droughts, earthquakes, wildfires, terror attacks, domestic violence, economic crises, and climate change). Data were collected throughout a one-week period in August and November 2020. The samples were independent, and derived from two existing survey panels of 100,000 individuals in each country, set up by Kantar Sifo marketing research company ${ }^{28}$, and should be considered representative of the Swedish and Italian population. 4,154 individuals participated in the survey in August $(\mathrm{N}=2,033$, mean age 50.3 years, $53.0 \%$ of females in Italy and $N=2,121$, mean age 49.3 years, $49.9 \%$ of females in Sweden) and 4,168 in November $(N=2,004$, mean age 49.4 years, $50.7 \%$ of females in Italy and $N=2,164$, mean age 47.9 years, $51.4 \%$ of females in Sweden). 
Individuals that lived in the capital region were overrepresented, specific weights were applied in the analysis to take this into account. The present study was approved by the Italian Research Ethics and Bioethics Committee (Dnr 0043071/2019) and the Swedish Ethical Review Authority (Dnr 2019-03242). The study was carried out in accordance with the ethical standards set by the European Union under Horizon 2020 (EU General Data Protection Regulation and FAIR Data Management). Participants were informed that the participation was voluntary and they consented to participate in this study by completing the survey.

\section{Risk perception of epidemics}

The present study considered the public risk perception of epidemics considering seven domains: the likelihood of epidemics, epidemic impact on the individual and on the population, individual and authority preparedness, individual and authority knowledge of epidemics with a Likert-type scale ranging from 1 , minimum to 5 , maximum.

\section{Predictors of the risk perception}

Information on direct experience of an epidemic and socio-economic factors such as age, gender, employment (yes vs. no), relative income (from 1 to 5), university education (yes vs. no) were collected in the survey and included in the present study as possible predictors of risk perception.

\section{Excess mortality}

Excess mortality at regional level in Italy and Sweden during the first wave of the COVID-19 pandemic (15th February-15th May for Italy and 1st March-31st May for Sweden) was considered in the study. Regional level was defined according to Nomenclature of Territorial Units for Statistics (NUTS) 2 classification of the European Union ${ }^{29}$. We retrieved data on excess mortality among the Italian regions from Scortichini et al. ${ }^{15}$. To estimate the excess mortality in Sweden, we compared the

COVID-19 outbreak with the pre-outbreak period. An interrupted time-series approach using Poisson models adjusted for seasonality, indicators for the day of the week, a term for the mean daily temperature from the ERA- 5 reanalysis data set on the Copernicus climate data store ${ }^{30}$ was applied to calculate the excess mortality on the Swedish regional level ${ }^{31}$. Mixed-effects models were used to calculate the excess mortality at regional (NUTS2) level.

\section{National policy response}

The Stringency index ${ }^{16}$ is a national response index and is used to quantify the measures implemented in response to the COVID-19 pandemic. The Stringency Index is a daily measure at country level that considers nine domains: school closures; workplace closures; cancellation of public events; restrictions on public gatherings; closures of public transport; stay-at-home requirements; public information campaigns; restrictions on internal movements; and international travel controls. In this paper, the level of national policy response was used as an ecological variable with four levels (Sweden up to August, Italy up to August, Sweden up to November and Italy up to November) and was defined as the area under the curve of 
the Stringency Index for each country, between two successive days up to the 5th August 2020 (first survey) and the 4th November 2020 (second survey). This measure was standardized on the value of Sweden in August (considered as the reference).

\section{Statistical analysis}

Possible differences in means and confidence intervals for seven items of risk perception between countries and over time were examined through a stratified analysis. Effect modification by country and period was examined by conventional additive and multiplicative terms using ordinal logistic regression with risk perception (independent variables) and country and period as dependent variables ${ }^{32}$.

Second, multivariable ordinal logistic regression models were performed to evaluate the association of gender, age, employment, relative income, university education and experience of epidemics as possible predictors with the seven domains of risk perception (independent variables). The analysis was stratified by country and period.

Third, we examined if the risk perception varied according to which extent an area was affected by the first wave of the COVID-19 pandemic. We compared the means and confidence intervals for seven items of risk perception between the most affected region in terms of excess mortality (Stockholm region in Sweden about $60 \%$ excess mortality and Lombardy region in Italy about $100 \%$ excess mortality) and comparison with the rest of the country. Then, ordinal logistic regression models were performed to examine if the excess mortality at regional level (dependent variable) was associated with domains of risk perception (independent variables) stratifying for country and adjusting for gender, age, and relative income. Finally, the association between the level of implemented measures and risk perception was explored using adjusted ordinal logistic regression models.

Results from logistic models were expressed in terms of Odds Ratio (OR) and 95\% Confidence Interval (CI).

Statistical analyses were performed using Stata version 15.0 (StataCorp, College Station, TX, USA) and R version 4.0.3.

\section{Declarations}

\section{Code availability}

Code for processing and graphically representing the data is available at https://github.com/eleraf/epidemics-risk-perception

\section{Acknowledgements}

This research has received funding by the European Research Council (ERC) within the project HydroSocialExtremes: Uncovering the Mutual Shaping of Hydrological Extremes and Society, ERC Consolidator Grant No. 771678, H2020 Excellent Science. The funder did not interfere in the research 
design, data collection and analysis, and in the preparation of the manuscript. Open Access funding provided by Uppsala University. We would like to thank Maurizio Mazzoleni for the support in preparing daily temperature data at regional level.

\section{Author contributions}

E.R., E.M. and G.D.B. conceived and designed the analysis. E.R. analyzed the data. E.R and E.M. prepared the figures. E.R. wrote the first draft of the paper, to which all authors contributed. All authors revised the final manuscript.

\section{Consent statement}

Participants were advised that participation was voluntary and that the survey was anonymous.

Informed consent was obtained from all participants. Participants gave consent for participation by completing the questionnaire.

\section{References}

1. Wachinger, G., Renn, O., Begg, C. \& Kuhlicke, C. The risk perception paradox-implications for governance and communication of natural hazards. Risk analysis: an official publication of the Society for Risk Analysis. 33, 1049-1065 https://doi.org/10.1111/j.1539-6924.2012.01942.x (2013).

2. Mondino, E., Scolobig, A., Borga, M. \& Di Baldassarre, G. The role of experience and different sources of knowledge in shaping flood risk awareness. 12,2130(2020).

3. Slovic, P. Trust, emotion, sex, politics, and science: surveying the risk-assessment battlefield. Risk analysis: an official publication of the Society for Risk Analysis. 19, 689-701 https://doi.org/10.1023/a:1007041821623 (1999).

4. Bubeck, P., Botzen, W. J. \& Aerts, J. C. A review of risk perceptions and other factors that influence flood mitigation behavior. Risk analysis: an official publication of the Society for Risk Analysis. 32, 1481-1495 https://doi.org/10.1111/j.1539-6924.2011.01783.x (2012).

5. Tversky, A., Kahneman, D. \& Availability A heuristic for judging frequency and probability. Cogn. Psychol. 5, 207-232 https://doi.org/10.1016/0010-0285(73)90033-9 (1973).

6. Espluga, J., Prades, A., Gamero, N. \& Solá, R. J. P. y. s. El papel de la confianza en los conflictos socio ambientales. 46, 255-273(2009).

7. Tang, C. S. \& Wong, C. Y. Factors influencing the wearing of facemasks to prevent the severe acute respiratory syndrome among adult Chinese in Hong Kong. Preventive medicine. 39, 1187-1193 https://doi.org/10.1016/j.ypmed.2004.04.032 (2004).

8. Rubin, G. J., Amlôt, R., Page, L. \& Wessely, S. Public perceptions, anxiety, and behaviour change in relation to the swine flu outbreak: cross sectional telephone survey. BMJ. 339, b2651 
https://doi.org/10.1136/bmj.b2651 (2009).

9. Kim, Y., Zhong, W., Jehn, M. \& Walsh, L. Public risk perceptions and preventive behaviors during the 2009 H1N1 Influenza Pandemic. Disaster Medicine and Public Health Preparedness. 9, 145-154 https://doi.org/10.1017/dmp.2014.87 (2015).

10. Kontis, V. et al. Magnitude, demographics and dynamics of the effect of the first wave of the COVID19 pandemic on all-cause mortality in 21 industrialized countries. Nature Medicine. 26, 1919-1928 https://doi.org/10.1038/s41591-020-1112-0 (2020).

11. United Nations Department of Economic and Social Affairs. World Population Ageing 2019. (2019).

12. ECDC. Data on hospital and ICU admission rates and current occupancy for COVID-19, https://www.ecdc.europa.eu/en/publications-data/download-data-hospital-and-icu-admission-ratesand-current-occupancy-covid-19

13. ECDC. Historical data (to 14 December 2020) on daily number of COVID-19 cases and deaths by country worldwide, https://www.ecdc.europa.eu/en/publications-data/download-todays-datageographic-distribution-covid-19-cases-worldwide

14. ECDC. Data on country response measures to COVID-19, https://www.ecdc.europa.eu/en/publicationsdata/download-data-response-measures-covid-19

15. Scortichini, M. et al. Excess mortality during the COVID-19 outbreak in Italy: a two-stage interrupted time-series analysis. International journal of epidemiology. 49, 1909-1917 https://doi.org/10.1093/ije/dyaa169 (2021).

16. Hale, T. et al. A global panel database of pandemic policies (Oxford COVID-19 Government Response Tracker). Nature human behaviour. https://doi.org/10.1038/s41562-021-01079-8 (2021).

17. Rogers, R. W. \& Prentice-Dunn, S. in Handbook of health behavior research 1: Personal and social determinants113-132(Plenum Press, 1997).

18. Rogers, R., Cacioppo, J. \& Petty, R.153-177(1983).

19. Bish, A. \& Michie, S. Demographic and attitudinal determinants of protective behaviours during a pandemic: a review. British journal of health psychology. 15, 797-824 https://doi.org/10.1348/135910710x485826 (2010).

20. Wang, P. W. et al. Sources of COVID-19-Related Information in People with Various Levels of Risk Perception and Preventive Behaviors in Taiwan: A Latent Profile Analysis. International journal of environmental research and public health. 18, https://doi.org/10.3390/ijerph18042091 (2021).

21. Wise, T., Zbozinek, T. D., Michelini, G., Hagan, C. C. \& Mobbs, D. Changes in risk perception and selfreported protective behaviour during the first week of the COVID-19 pandemic in the United States. Royal Society open science. 7, 200742 https://doi.org/10.1098/rsos.200742 (2020).

22. Finucane, M. L., Slovic, P., Mertz, C. K., Flynn, J. \& Satterfield, T. A. Gender, race, and perceived risk: The 'white male' effect. Health, Risk \& Society. 2, 159-172 https://doi.org/10.1080/713670162 (2000).

23. Mansilla Domínguez, J. M. et al. Risk Perception of COVID-19 community transmission among the Spanish population. International journal of environmental research and public health. 17, 8967 https://doi.org/10.3390/ijerph17238967 (2020). 
24. Dryhurst, S. et al. Risk perceptions of COVID-19 around the world. Journal of Risk Research. 23, 9941006 https://doi.org/10.1080/13669877.2020.1758193 (2020).

25. Mallapaty, S. The coronavirus is most deadly if you are older and male - new data reveal the risks. Nature. 585, 16-17 https://doi.org/10.1038/d41586-020-02483-2 (2020).

26. Ruck, D. J., Matthews, L. J., Kyritsis, T., Atkinson, Q. D. \& Bentley, R. A. The cultural foundations of modern democracies. Nature human behaviour. 4, 265-269 https://doi.org/10.1038/s41562-0190769-1 (2020).

27. Mondino, E., Di Baldassarre, G., Mård, J., Ridolfi, E. \& Rusca, M. Public perceptions of multiple risks during the COVID-19 pandemic in Italy and Sweden. Scientific Data. 7, 434 https://doi.org/10.1038/s41597-020-00778-7 (2020).

28. Sifo, K. https://www.kantarsifo.se/om-oss

29. EU. Amending Regulation (EC) No 1059/2003 as regards the territorial typologies (Tercet), https://eurlex.europa.eu/legal-content/EN/TXT/?uri=celex\%3A32017R2391

30. ECMWF. ERA5 hourly data on single levels from 1979 to present, https://cds.climate.copernicus.eu/cdsapp\#!/dataset/reanalysis-era5-single-levels? tab = form

31. SCB, SCB publicerar preliminär statistik över döda i Sverige, https://www.scb.se/om-scb/nyheter-ochpressmeddelanden/scb-publicerar-preliminar-statistik-over-doda-i-sverige (2021).

32. Knol, M. J. \& VanderWeele, T. J. Recommendations for presenting analyses of effect modification and interaction. International journal of epidemiology 41, 514-520, doi:10.1093/ije/dyr218 \%J International Journal of Epidemiology (2012).

\section{Figures}
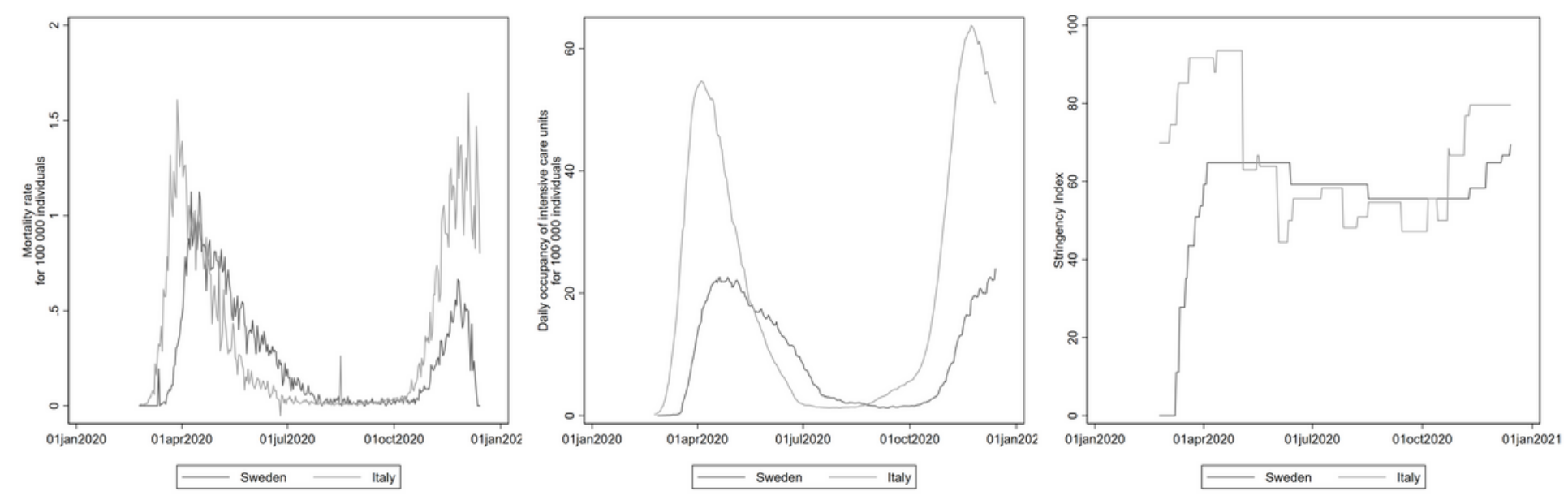

Figure 1

Mortality rate and daily occupancy of intensive care unit rate for COVID-19 per 100000 individuals and the level of restrictive measures - the Stringency Index - in Italy and Sweden during 2020. The Stringency Index considers 9 domains (school closures, workplace closures, cancellation of public events, restrictions on 
public gatherings, closures of public transport, stay-at-home requirements, public information campaigns, restrictions on internal movements, and international travel controls).

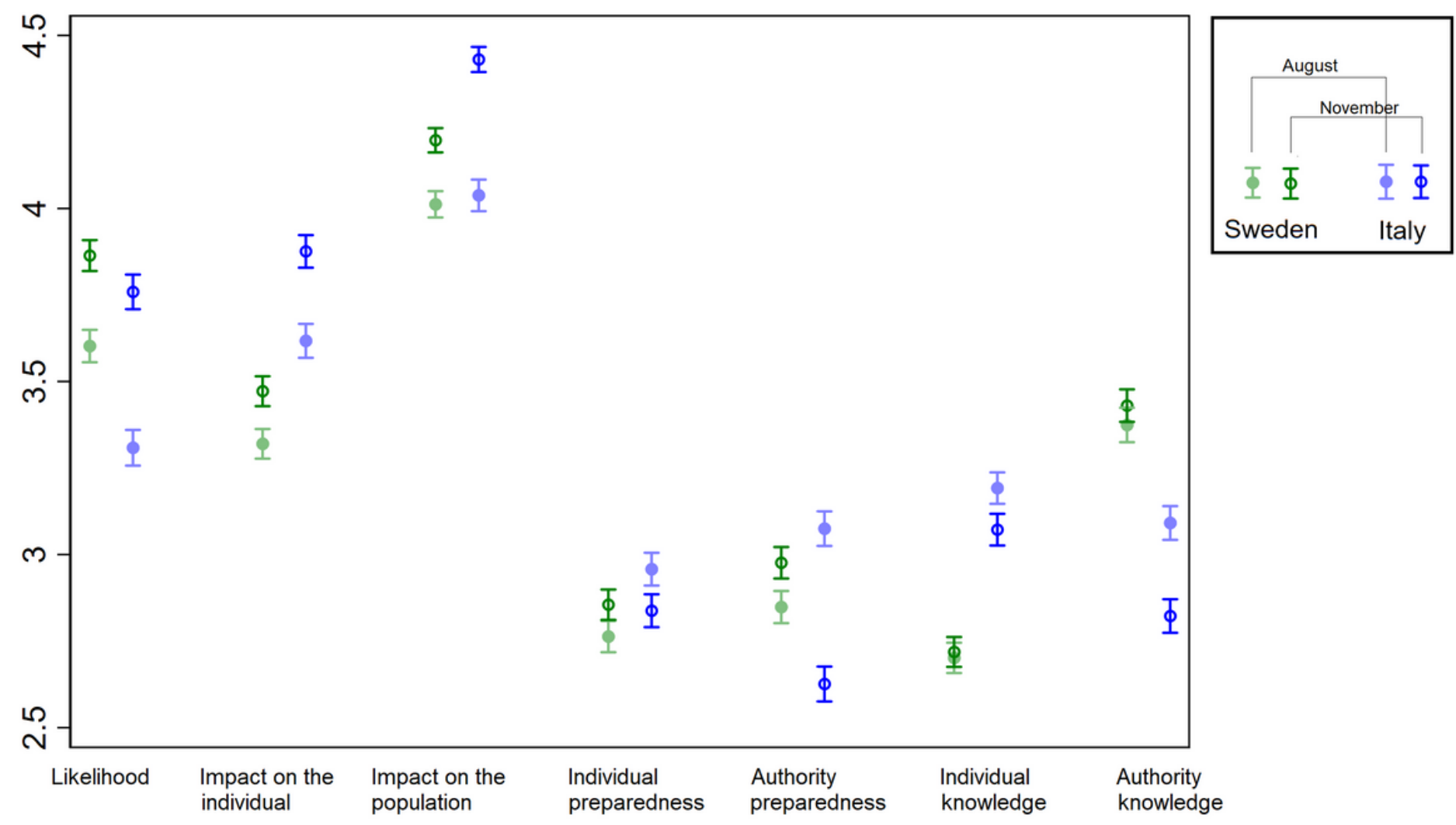

Figure 2

Means and 95\% Cls for epidemic risk perception (likelihood, impact on the individual, impact on the population, individual preparedness, authority preparedness, individual knowledge, authority knowledge) by country and period.

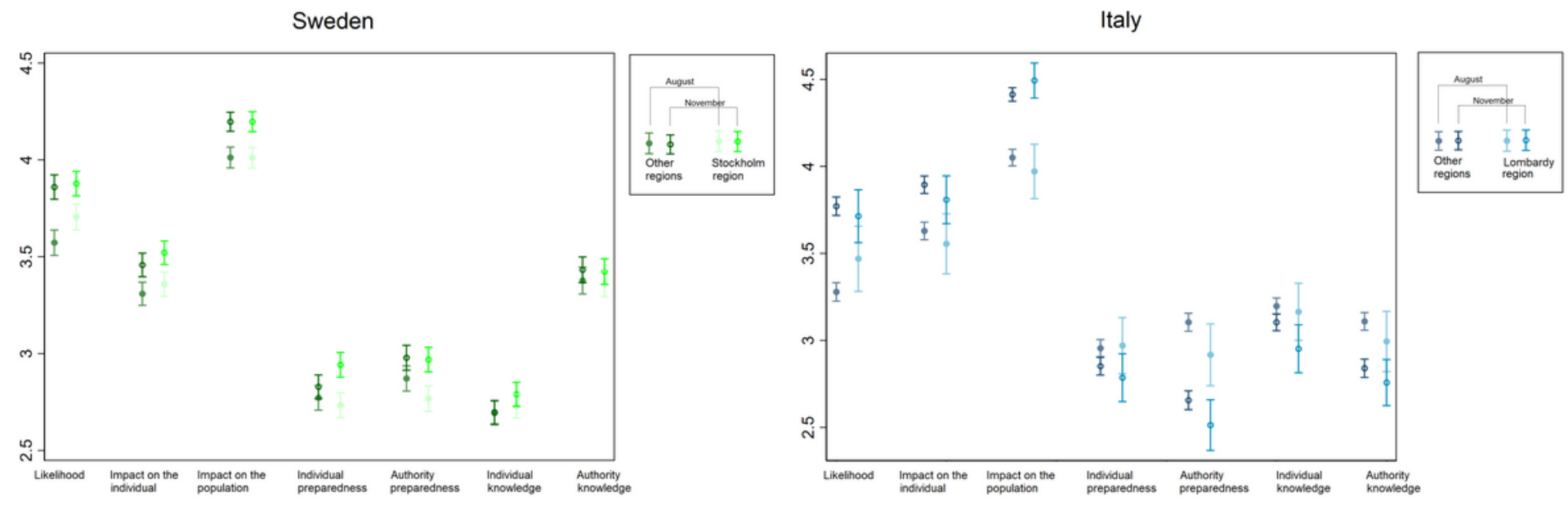

Figure 3

Means and $95 \%$ Cls for epidemic risk perception in Sweden and Italy by affected areas and period. 


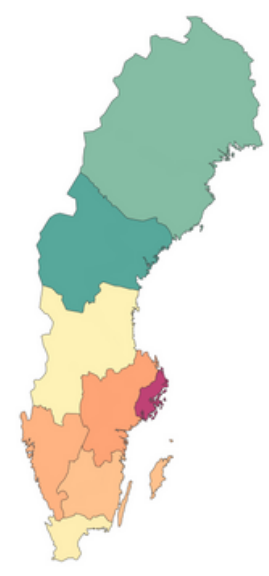

Execess Mortality \begin{tabular}{llllll}
\hline 150 & 25 & 50 & 75 & 100 & 125
\end{tabular}

\section{Sweden}

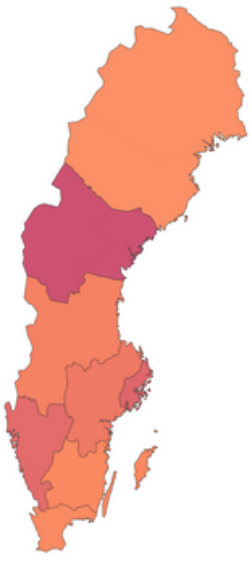

Likelihood

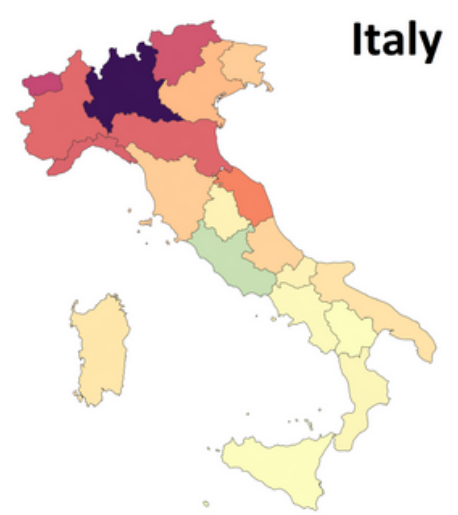

Execess Mortality
\begin{tabular}{llllll}
\hline-150 & 25 & 50 & 75 & 100 & 125
\end{tabular}

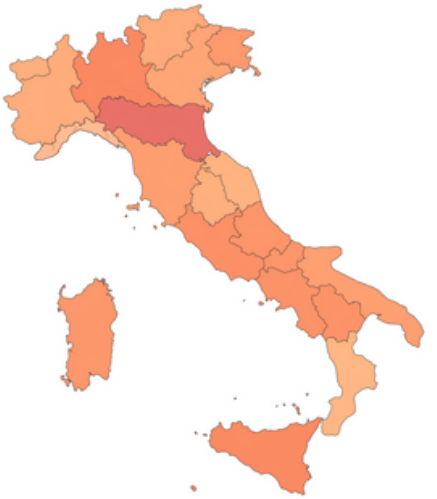

Likelihood

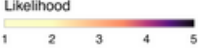

\section{Figure 4}

Perception of likelihood of epidemics after the first wave (August survey) and excess mortality during the first wave (15th February-15th May for Italy and 1st March-31st May for Sweden) stratified by region level. Note: The designations employed and the presentation of the material on this map do not imply the expression of any opinion whatsoever on the part of Research Square concerning the legal status of any country, territory, city or area or of its authorities, or concerning the delimitation of its frontiers or boundaries. This map has been provided by the authors. 